\title{
Teaching NeuroImages: Stroke With Nondecussating Corticospinal Tracts Causing Ipsilateral Weakness
}

\section{Straight Forward}

Lily W. Zhou, MD, Jason Chew, MBChB, FRCPC, and Thalia S. Field, MHSc, MD, FRCP

Neurology ${ }^{\circledR}$ 2021;96:e480-e481. doi:10.1212/WNL.0000000000010804

Figure 1 CT Angiogram and Diffusion Weighted MRI
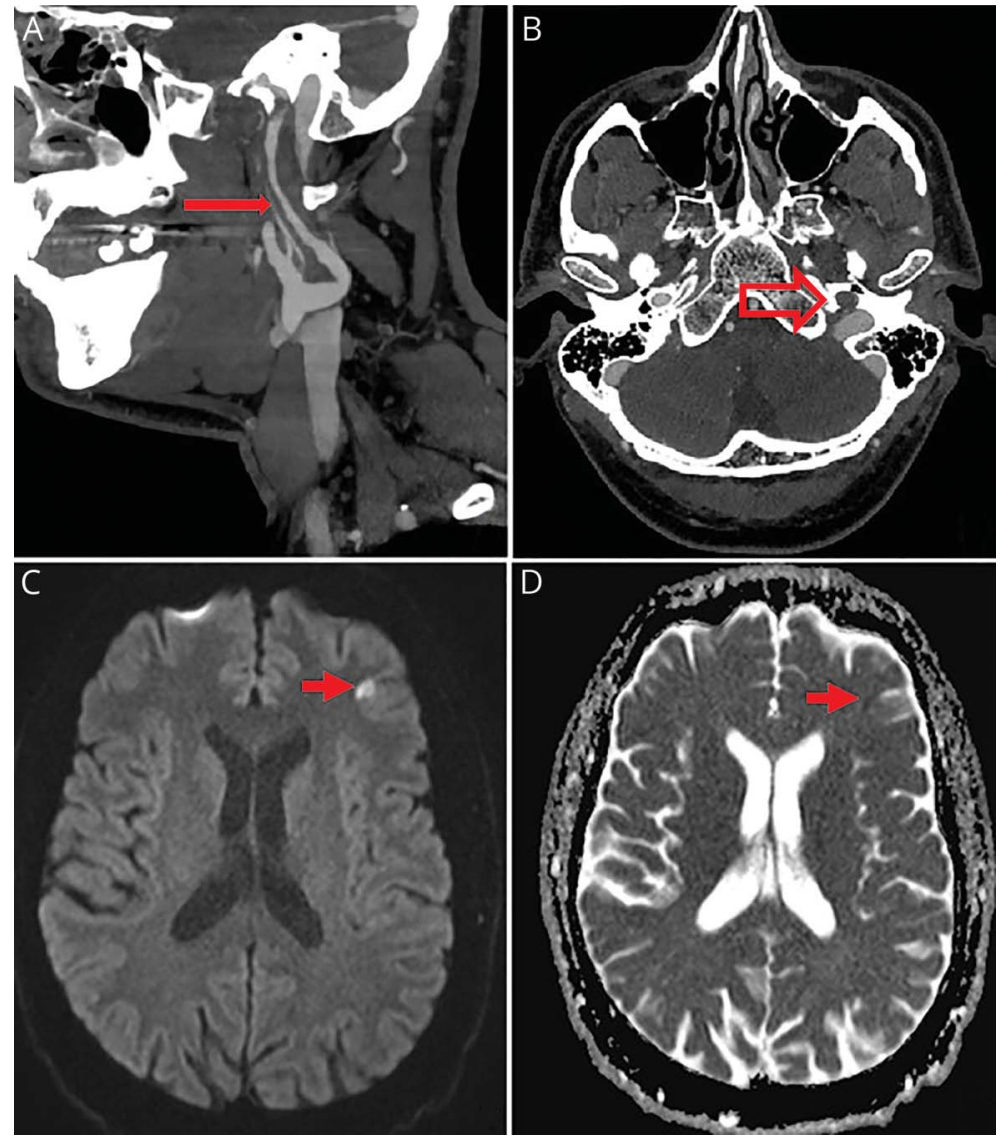

CT angiogram showing left carotid dissection with luminal irregularity and mural thickening of the left carotid from C2 up to the carotid canal on sagittal image (panel A, long solid arrow) and reduced opacification at the carotid canal on axial image (panel B, large hollow arrow). Axial MRI head showing restricted diffusion on B1000 diffusion weighted imaging (panel C, short solid arrow) and apparent diffusion coefficient (panel $D$, short solid arrow) demonstrating left-sided subacute frontal stroke.

A 43-year-old man presented with left carotid dissection. Examination showed left-sided Horner, left facial weakness, and left pronator drift. MRI brain showed a small left frontal infarct (figure 1), with no other areas of infarction and nondecussating corticospinal tracts on diffusion tensor imaging (figure 2).
Correspondence

Dr. Field

thalia.field@ubc.ca
MORE ONLINE

$\rightarrow$ Teaching slides

links.lww.com/WNL/

B212

From the Department of Neurology (L.W.Z., T.S.F.), University of British Columbia; and Department of Radiology (J.C.), University of British Columbia, Vancouver, Canada. Go to Neurology.org/N for full disclosures. Funding information and disclosures deemed relevant by the authors, if any, are provided at the end of the article. 

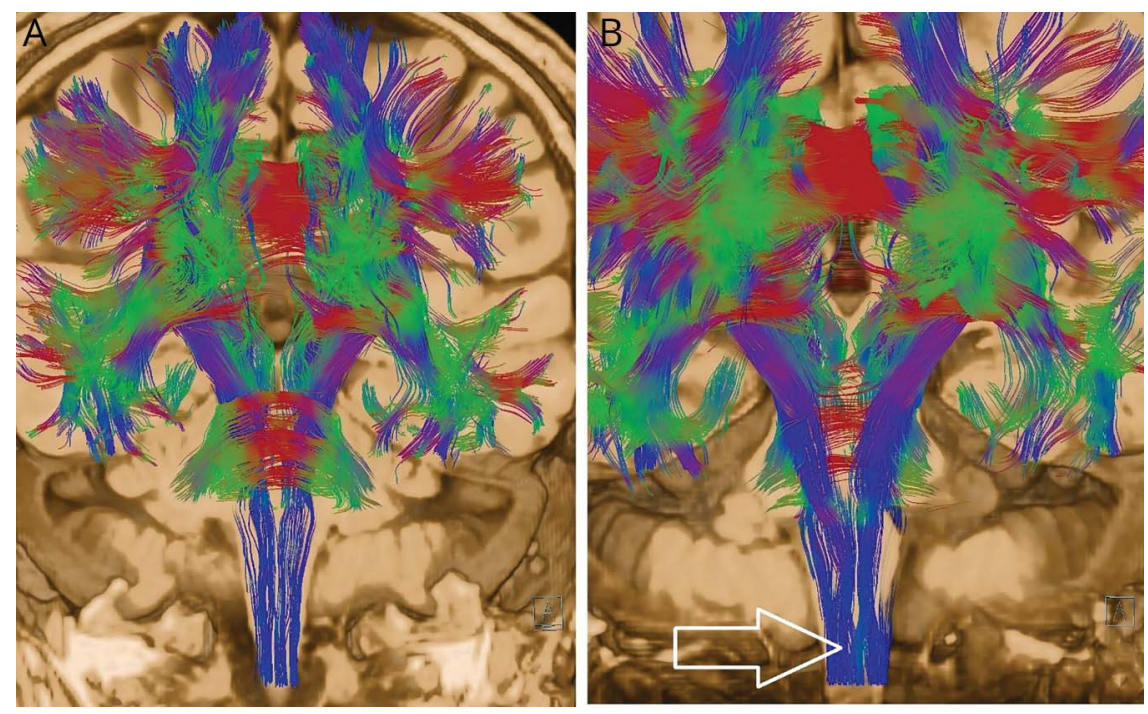

Coronal reformatted diffusion tensor imaging showing nondecussation of white matter tracts in the caudal medulla (panel A) compared with normal control (panel B, arrow showing decussation).

Several congenital syndromes are associated with nondecussating tracts and mirror movements. ${ }^{1}$ The prevalence of nondecussating corticospinal tracts in the general population is unknown. Ipsilateral hemiparesis is also reported with previous contralateral infarcts possibly from the disruption of compensating normal uncrossed corticospinal fibres. ${ }^{2}$ This patient has no baseline impairment and demonstrates nondecussating tracts as an anatomical variant.

\section{Study Funding}

No targeted funding reported.

\section{Disclosure}

The authors report no disclosures relevant to the manuscript. Go to Neurology.org/N for full disclosures.

\section{Appendix Authors}

\begin{tabular}{lll}
\hline Author & Location & Contribution \\
\hline $\begin{array}{l}\text { Lily W. Zhou, } \\
\text { MD }\end{array}$ & $\begin{array}{l}\text { University of British } \\
\text { Columbia, } \\
\text { Vancouver, Canada }\end{array}$ & $\begin{array}{l}\text { Drafted the manuscript for } \\
\text { intellectual content and } \\
\text { prepared the figures for } \\
\text { publications }\end{array}$ \\
\hline $\begin{array}{l}\text { Jason Chew, } \\
\text { MBChB, }\end{array}$ & $\begin{array}{l}\text { University of British } \\
\text { FRCPC }\end{array}$ & $\begin{array}{l}\text { Revised the manuscript for } \\
\text { intellectual content and } \\
\text { prepared the figures for } \\
\text { publications }\end{array}$ \\
\hline $\begin{array}{l}\text { Thalia S. } \\
\text { Field, MHSc, } \\
\text { MD, FRCPC }\end{array}$ & $\begin{array}{l}\text { University of British } \\
\text { Columbia, }\end{array}$ & $\begin{array}{l}\text { Drafted the manuscript for } \\
\text { intellectual content and } \\
\text { Cancouver, Canada } \\
\text { for informed consent }\end{array}$ \\
& &
\end{tabular}

\section{References}

1. Sag E, Gocmen R, Yildiz FG, et al. Congenital mirror movements in Gorlin syndrome: a case report with DTI and functional MRI features. Pediatrics 2016;137:e20151771.

2. Inatomi $\mathrm{Y}$, Nakajima M, Yonehara $\mathrm{T}$, Ando Y. Ipsilateral hemiparesis in ischemic stroke patients. Acta Neurol Scand 2017;136:31-40. 


\section{Neurology}

\section{Teaching NeuroImages: Stroke With Nondecussating Corticospinal Tracts Causing Ipsilateral Weakness: Straight Forward \\ Lily W. Zhou, Jason Chew and Thalia S. Field}

Neurology 2021;96;e480-e481 Published Online before print September 9, 2020

DOI 10.1212/WNL.0000000000010804

This information is current as of September 9, 2020

Updated Information \& Services

References

Subspecialty Collections

Permissions \& Licensing

Reprints including high resolution figures, can be found at: http://n.neurology.org/content/96/3/e480.full

This article cites 2 articles, 0 of which you can access for free at: http://n.neurology.org/content/96/3/e480.full\#ref-list-1

This article, along with others on similar topics, appears in the following collection(s):

All Cerebrovascular disease/Stroke

http://n.neurology.org/cgi/collection/all_cerebrovascular_disease_strok

All Education

http://n.neurology.org/cgi/collection/all_education

Cortical localization

http://n.neurology.org/cgi/collection/cortical_localization MRI

http://n.neurology.org/cgi/collection/mri

Information about reproducing this article in parts (figures,tables) or in its entirety can be found online at:

http://www.neurology.org/about/about_the_journal\#permissions

Information about ordering reprints can be found online:

http://n.neurology.org/subscribers/advertise

Neurology ${ }^{\circledR}$ is the official journal of the American Academy of Neurology. Published continuously since 1951, it is now a weekly with 48 issues per year. Copyright () 2020 American Academy of Neurology. All rights reserved. Print ISSN: 0028-3878. Online ISSN: 1526-632X.

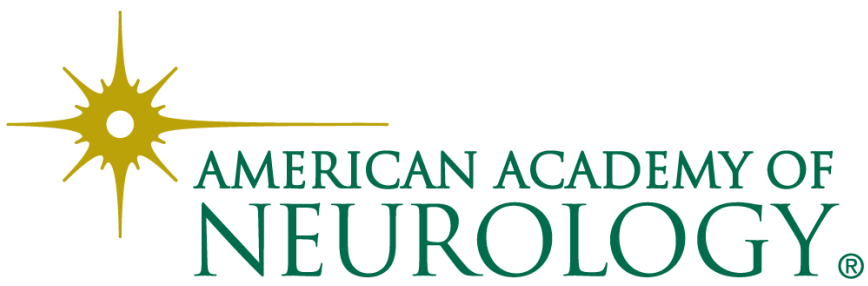

